\title{
Article \\ Sequestration of Mercury in Soils under Scots Pine and Silver Fir Stands Located in the Proximity to a Roadway
}

\author{
Piotr Gruba *, Mateusz Kania, Dawid Kupka (D) and Marcin Pietrzykowski \\ Department of Forest Ecology and Sylviculture, Faculty of Forestry, University of Agriculture in Kraków, \\ 31-425 Kraków, Poland; matikania@o2.pl (M.K.); dawid.kupka@student.urk.edu.pl (D.K.); \\ m.pietrzykowski@urk.edu.pl (M.P.) \\ * Correspondence: piotr.gruba@urk.edu.pl; Tel.: +48-126-625-033
}

check for updates

Citation: Gruba, P.; Kania, M.; Kupka, D.; Pietrzykowski, M. Sequestration of Mercury in Soils under Scots Pine and Silver Fir Stands Located in the Proximity to a Roadway. Int. J. Environ. Res. Public Health 2021, 18, 4569. https:// doi.org/10.3390/ijerph18094569

Academic Editors: Bozena Smreczak, Alicja Kicinska and Eleonora Wcisło

Received: 28 March 2021

Accepted: 23 April 2021

Published: 26 April 2021

Publisher's Note: MDPI stays neutral with regard to jurisdictional claims in published maps and institutional affiliations.

Copyright: (c) 2021 by the authors. Licensee MDPI, Basel, Switzerland. This article is an open access article distributed under the terms and conditions of the Creative Commons Attribution (CC BY) license (https:// creativecommons.org/licenses/by/ $4.0 /)$.

\begin{abstract}
Forest soils are the main source of mercury $(\mathrm{Hg})$ in stream water. Stocks of $\mathrm{Hg}$ in forest soils are related to several factors, including forest species composition. In this study, the potential source of $\mathrm{Hg}$ pollution was a relatively new roadway traversing forested areas. We compared $\mathrm{Hg}$ accumulation in soils of two coniferous species: Scots pine (Pinus sylvestris L.) and silver fir (Abies alba Mill.). The experimental plots were located near the S7 expressway in Central Poland. The stands differed in the length of time they had been exposed to $\mathrm{Hg}$, because different parts of the roadway were built and opened to traffic at different times. We analyzed 480 soil samples from organic horizons $(\mathrm{O})$ and the top $10 \mathrm{~cm}$ of mineral soil (A) sampled from six plots. The overall average $\mathrm{Hg}$ concentrations (irrespective of forest stand, $n=240$ ) was $0.225 \mathrm{mg} \mathrm{kg}^{-1}$ in the O horizons and $0.075 \mathrm{mg} \mathrm{kg}^{-1}$ in the mineral horizons. The $\mathrm{Hg}$ concentration in the $\mathrm{O}$ horizons was more than three times greater in fir stands than that in pine stands. The average $\mathrm{Hg}: \mathrm{C}$ ratios in the $\mathrm{O}$ and $\mathrm{A}$ horizons were 1.0 and $2.3 \mathrm{mg} \mathrm{Hg} \mathrm{kg}^{-1} \mathrm{C}$, respectively. Our data does not clearly show the effect of road on $\mathrm{Hg}$ accumulation near the road. The concentrations of $\mathrm{Hg}$ in investigated soils adjacent to the roadway were only slightly higher than ranges reported for unpolluted areas, and no clearly affected by the vicinity of roadway. In contrast to the other reports, our data indicate a significant impact of tree species on $\mathrm{Hg}$ concentrations in both the $\mathrm{O}$ and $\mathrm{A}$ horizons. Moreover, the average $\mathrm{Hg}: \mathrm{C}$ ratio was strongly dependent on the tree species.
\end{abstract}

Keywords: Abies alba; forest soils; $\mathrm{Hg}: \mathrm{C}$ ratio; mercury; Pinus sylvestris; road pollution

\section{Introduction}

Mercury $(\mathrm{Hg})$ in soil originates from atmospheric deposition, and the $\mathrm{Hg}$ pools in soil depend largely on the vegetation type, particularly in forest ecosystems [1-3]. Retention of $\mathrm{Hg}$ in forest soils is attributed to the affinity of $\mathrm{Hg}$ for soil organic matter (SOM) [2,4-7]. Soil $\mathrm{Hg}$ compounds are bound to organic matter [4,8] and form complexes with thiol groups (R-S-H) [2] in the SOM. The content of organic matter and particle size composition are spatially variable soil characteristics, thus the degree of $\mathrm{Hg}$ accumulation is not constant in any given area, but varies depending on local heterogeneity of organic matter, soil texture, and elevation [3]. Given that forest areas are one of the main sources of $\mathrm{Hg}$ in stream water $[9,10]$, understanding how $\mathrm{Hg}$ accumulates in, and mobilizes from, forest soils is important to understand how atmospheric $\mathrm{Hg}$ ultimately affects aquatic ecosystems.

Road traffic is a potential source of $\mathrm{Hg}$. Several authors have suggested that traffic emissions and other related anthropogenic activities are potential sources of metal contamination (for example, via roadway dust). However, few studies have focused on $\mathrm{Hg}$ pollution near roads [11,12]. According to Jiang et al. [13], coal and oil combustion are the most important sources of global atmospheric $\mathrm{Hg}$, particularly in China, where about $75 \%$ of $\mathrm{Hg}$ emissions were related to the combustion of fossil fuels. According to Petroleum statistics [14], some kinds of gasoline contain 0.2-3.3 $\mathrm{ng} \mathrm{g}^{-1}$ of $\mathrm{Hg}$. Pirrone et al. [15] reported that the global $\mathrm{Hg}$ emission from petrol and diesel oil combustion is $378 \mathrm{~kg}$ per year. Traffic 
emission was regarded as the most important anthropogenic metal (including $\mathrm{Hg}$ ) source by Liu et al. [16] and Liang et al. [17]. Also Ozaki et al. [18] found increased levels of $\mathrm{Hg}$ in roadside dust and soils. Research sites are strongly affected by the presence of automobiles, which is believed to be responsible for the higher concentrations.

Soil C, particle size composition and altitude are most important factors affecting $\mathrm{Hg}$ content in forest soils [3,19]. The influence of forest type is also important, because the quality and content of SOM in forest soils are strongly affected by the forest tree species [3]. Thus, it is expected that forest species composition will affect $\mathrm{Hg}$ accumulation in soils. Previous studies have detected clear differences in the ability of certain tree species (particularly coniferous vs. broadleaf) to intercept atmospheric deposition [19-24]. Given that $\mathrm{C}$ is a major variable affecting the $\mathrm{Hg}$ concentration in soil, the effects of other variables (e.g., distance from the pollution sources or the effect of tree species) can be difficult to detect. Thus, $\mathrm{Hg}$ to carbon (C) or sulfur (S) ratios are sometimes used as a reliable standardization method [3,24].

The intensive industrial and urban development in Poland has led to the deforestation of large forest areas to accommodate new roadways.

In this study, we tested the hypothesis that two coniferous species with different scavenging abilities, Scots pine (Pinus sylvestris L.) and silver fir (Abies alba Mill.), significantly affect $\mathrm{Hg}$ sequestration close to a roadway. Given the importance of SOM for $\mathrm{Hg}$ sequestration, we also analyzed $\mathrm{Hg}$ to $\mathrm{C}$ and $\mathrm{Hg}$ to $\mathrm{S}$ stoichiometry in detail.

\section{Materials and Methods}

\subsection{Study Site}

The six study plots were located near roadway S7, between the cities of SkarzyskoKamienna and Kielce, central Poland. These plots were established in Scots pine (Pinus sylvestris L.) and Silver fir (Abies alba Mill.) forest stands, on soils developed from three kinds of parent materials (Table 1). According to the Geological Map of Poland [25], the local soils are formed of Quaternary sands that originated from weathering sandstones, Triassic sandstones formed in the lower Triassic, and Cambrian sandstones. The soils were classified as Cambisols and Podzols [26]. The terrain at the study site was relatively simple, and the elevation varied from 253 to $340 \mathrm{~m}$ above sea level. Forest stands with fir were unevenly aged with a multistoried texture, whereas Scots pine forests were evenly aged and one-storied (Table 1).

Table 1. Characteristics of six study plots and reference area.

\begin{tabular}{|c|c|c|c|c|}
\hline Plot Number & $\begin{array}{l}\text { Geographical } \\
\text { Coordinates }\end{array}$ & Parent Material & $\begin{array}{c}\text { Forest Stand } \\
\text { Species and Age } \\
\text { (Years) }\end{array}$ & $\begin{array}{c}\text { Year S7 } \\
\text { Expressway } \\
\text { Opened }\end{array}$ \\
\hline 1 & $\begin{array}{l}\text { N } 5100.659 \\
\text { E } 2048.551\end{array}$ & Triassic sandstones & $\begin{array}{l}\text { Silver fir (113) } \\
\text { Abies alba Mill. }\end{array}$ & 2011 \\
\hline 2 & $\begin{array}{l}\text { N } 5101.137 \\
\text { E } 2048.810\end{array}$ & Triassic sandstones & $\begin{array}{l}\text { Scots pine (53) } \\
\text { Pinus sylvestris L. }\end{array}$ & 2011 \\
\hline 3 & $\begin{array}{l}\text { N } 5055.984 \\
\text { E } 2039.586\end{array}$ & Cambrian sandstones & $\begin{array}{l}\text { Silver fir (93) } \\
\text { Abies alba Mill. }\end{array}$ & 1984 \\
\hline 4 & $\begin{array}{l}\text { N } 5056.024 \\
\text { E } 2039.519\end{array}$ & Cambrian sandstones & $\begin{array}{l}\text { Silver fir (94) } \\
\text { Abies alba Mill. }\end{array}$ & 2011 \\
\hline 5 & $\begin{array}{l}\text { N } 5053.471 \\
\text { E } 2031.560\end{array}$ & Quaternary sands & $\begin{array}{l}\text { Scots pine }(88) \\
\text { Pinus sylvestris L. }\end{array}$ & 2011 \\
\hline 6 & $\begin{array}{l}\text { N } 5053.500 \\
\text { E } 2031.677\end{array}$ & Quaternary sands & $\begin{array}{l}\text { Scots pine (57) } \\
\text { Pinus sylvestris L. } \\
\text { Silver fir }\end{array}$ & 1984 \\
\hline $\begin{array}{c}\text { Reference area } \\
{[27]}\end{array}$ & $\begin{array}{l}\text { N } 510142.92 \\
\text { E } 204332.97\end{array}$ & Triassic sandstones & $\begin{array}{l}\text { Abies alba Mill. } \\
\text { European beech } \\
\text { Fagus sylvativa L. }\end{array}$ & - \\
\hline
\end{tabular}


The investigation sites were relatively close $(5-16 \mathrm{~km})$ to the reference area investigated previously by Gruba et al. [27]. The area was established on similar type of parent material (see Figure $1 \mathrm{~b}$ and Table 1). Due to long distance to the nearest road or any potential source of $\mathrm{Hg}$, the area was considered to be relatively unpolluted.

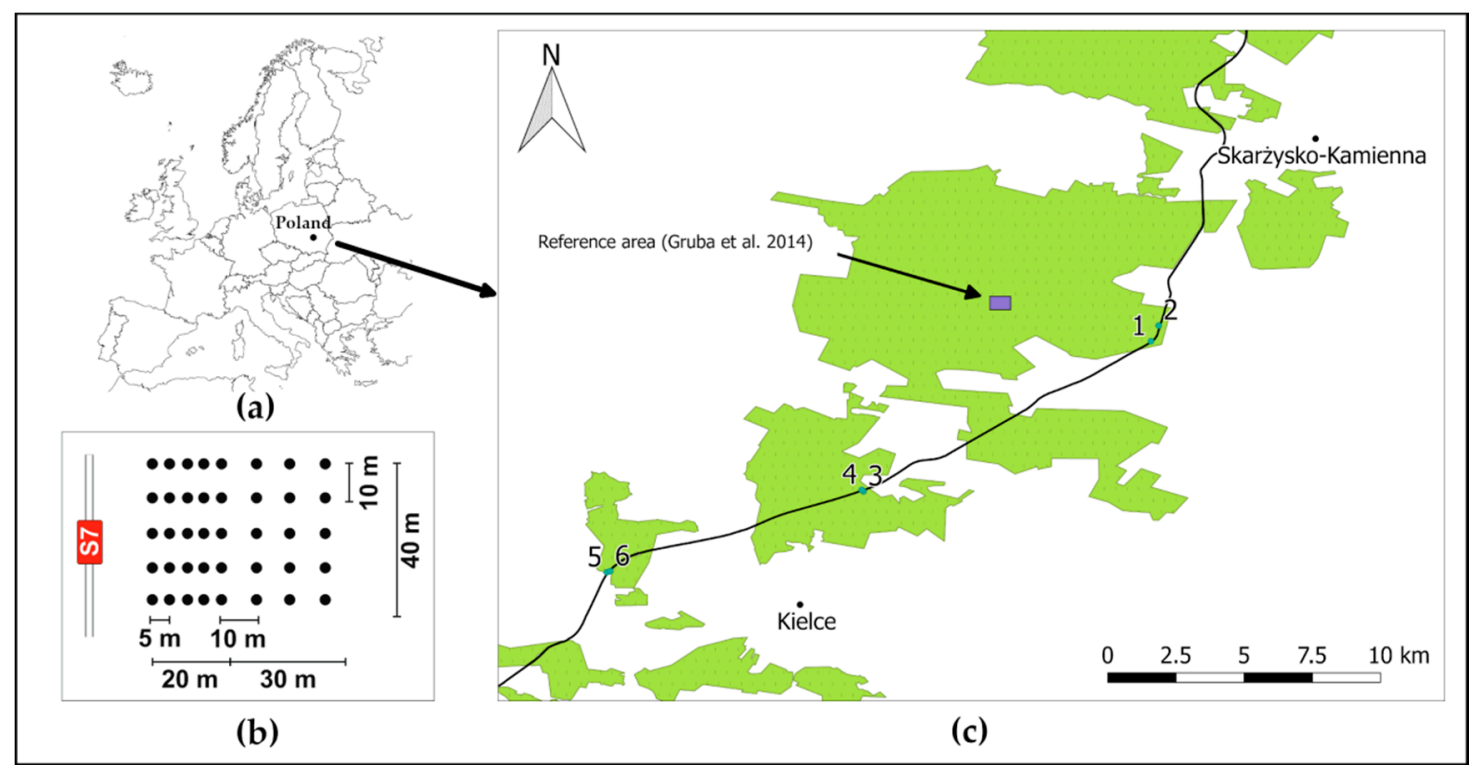

Figure 1. Location of the study sites and the reference area: (a) Location of Poland in Europe; (b) sampling scheme in each plot; (c) locations of the study plots near the S7 roadway and the reference area (blue rectangle).

At each plot the sampling points were located according to the scheme shown in Figure 1. Soil samples were taken from various distances from the road, from the organic horizon $(\mathrm{O})$ and first $10 \mathrm{~cm}$ of the mineral $(\mathrm{A})$ horizon.

\subsection{Laboratory Analyses}

Prior to analysis, soil samples were air-dried at room temperature and then sieved through $2 \mathrm{~mm}$ mesh. We used $2 \mathrm{~mm}$-sieved samples for measurement of the particle size composition by laser diffractor (Fritsch Analysette 22, Fritsch, Idar-Oberstein, Germany). The $\mathrm{pH}$ was measured potentiometrically with a combination electrode in a suspension with distilled water $(1: 5, w / v)$ after $24 \mathrm{~h}$ of equilibration. Cation exchange capacity (CEC) was estimated a sum of exchangeable cations $\left(B C=\mathrm{Ca}^{2+}+\mathrm{Mg}^{2+}+\mathrm{K}^{+}+\mathrm{Na}^{+}\right)$and total acidity (TA). Exchangeable cations were extracted with $1 \mathrm{~mol} \mathrm{~L}^{-1} \mathrm{NH}_{4} \mathrm{Cl}$ and determined by an ICP (ICP-OES Thermo iCAP 6500 DUO, Thermo Fisher Scientific, Cambridge, UK). TA was measured after extraction of soilwith $1 \mathrm{~mol} \mathrm{~L}^{-1}\left(\mathrm{CH}_{3} \mathrm{COO}\right)_{2} \mathrm{Ca}$ and determined using automatic titrator, Mettler Toledo, Inc. to $\mathrm{pH} 8.2$ with $0.1 \mathrm{~mol} \mathrm{~L}^{-1} \mathrm{NaOH}$. Soil subsamples were ground into a fine powder using a ball mill (Fritsch) to improve homogeneity. These fine samples were used to measure the total $\mathrm{Hg}$ content with a direct $\mathrm{Hg}$ analyzer DMA80 (Milestone, Sorisole, Italy). To assure the quality control (QC) of $\mathrm{Hg}$ measurements, the analysis included standard European Reference Material (ERM) $\mathrm{N}_{\mathrm{o}}$ CC141 (Loamy Soil), with certified value $\mathrm{Hg}=0.083 \mathrm{mg} \mathrm{kg}^{-1}$, uncertainty $0.017 \mathrm{mg} \mathrm{kg}^{-1}$, recovery between 80 and $120 \%$. Analysis of ERM was performed at the beginning and the end of each experimental series. ERM and each sample were analysed in two replicates, with permissible difference between the measurements $<10 \%$. The limit of quantitation was $0.003 \mathrm{mg} \mathrm{kg}^{-1}$. The fine subsamples were also used to measure the contents of soil carbon (C) and S with a LECO CNS TrueMac analyzer (Leco, St. Joseph, MI, USA). Since all soils were carbonate-free we assumed that $\mathrm{C}$ equals organic carbon.

In order to estimate the bulk density, a separate samples were taken. A $20 \mathrm{~cm} \times 20 \mathrm{~cm}$ frame was used to the sampling of organic $(\mathrm{O})$ horizon. The thickness of the organic horizon 
was measured during sampling. Samples from mineral soil horizons were sampled with metal cores $\left(250 \mathrm{~cm}^{3}\right)$. Samples were weighed after drying at $105^{\circ} \mathrm{C}$ for $24 \mathrm{~h}$.

Soil $\mathrm{Hg}$ pools were calculated per 1 square meter as the sum of $\mathrm{Hg}$ pools in the $\mathrm{O}$ and A horizons, based on measured $\mathrm{Hg}$ concentrations and bulk densities for each horizon.

\subsection{Statistical Analyses}

The dataset was divided into groups by the plot, tree species, or distance from the roadway edge and descriptive statistics were calculated. To analyze differences in the $\mathrm{Hg}$, and $\mathrm{C}$ contents, as well as the $\mathrm{Hg}: \mathrm{C}$ ratio, and other soil properties measured the different groups, $\mathrm{Z}$ test was performed to test statistical differences between pairs or Kruskal-Wallis was performed to compare multiple independent groups. Significance was accepted at $p<0.05$. Relationships between variables were investigated by performing correlation and regression analyses. We used the Pearson product-moment correlation coefficient ( $\mathrm{r}$ ). Multiple regression was used to evaluate the relationships between $\mathrm{Hg}$ and independent variables (i.e., soil properties and forest stands characteristics). The $\mathrm{Hg}$ and $\mathrm{C}$ content data were log-transformed to approach data normal distribution. All statistical analyses were performed using STATISTICA 12 software (StatSoft, Tulsa, OK, USA).

\section{Results}

The properties of the investigated soils of the fir and pine stands differed considerably. Soils of pine stands, derived from glacio-fluvial deposits, were sandy (average contents: sand $78 \%$, silt $19 \%$ and clay $3 \%$ ). Soils of fir stands, developed on weathered sandstones, were siltic (average contents: silt 57\%, sand 35\%, clay 7\%). Soil of fir stands also had more organic carbon accumulated in both the $\mathrm{O}$ and mineral A horizons (Table 2), resulting in higher $\mathrm{C}$ contents in soils of fir $\left(6.52 \mathrm{~kg} \mathrm{C} \mathrm{m}^{-2}\right)$ than in soils of pine $\left(4.32 \mathrm{~kg} \mathrm{C} \mathrm{m}^{-2}\right)$. Note that at the investigated depth, the majority of C $(\sim 60 \%)$ was allocated to the mineral $\mathrm{A}$ horizon $(10 \mathrm{~cm})$. The $\mathrm{S}$ content was significantly higher in soils of fir stands (both in the $\mathrm{O}$ and A horizons) than in soils of pine stands. Both fir and pine soils were strongly acidic (Table 2), but soils of pine stands had significantly higher $\mathrm{pH}$ values. Considering vertical differences in $\mathrm{pH}$, the average $\mathrm{pH}$ values of the $\mathrm{O}$ and $\mathrm{A}$ horizons of pine stands were not significantly different, whereas the $\mathrm{O}$ horizons had significantly higher $\mathrm{pH}$ values than those of the mineral (A) horizons in soils of fir stands (Table 2).

Table 2. Comparison of selected properties of soils of fir and pine stands (mean \pm standard deviation). All paired averages from fir and pine stand are significantly different $(\mathrm{Z}$ test, $p<0.001)$.

\begin{tabular}{|c|c|c|c|c|c|c|c|c|c|}
\hline \multirow{2}{*}{$\begin{array}{l}\text { Dominant } \\
\text { Tree Species }\end{array}$} & \multirow{2}{*}{$n$} & $\mathrm{C}$ & $\mathbf{S}$ & $\mathrm{pH}_{\mathrm{H} 2 \mathrm{O}}$ & $\mathrm{Hg}$ & $\mathrm{Hg}: \mathrm{C}$ & \multirow{2}{*}{ Hg:S } & \multirow{2}{*}{$\begin{array}{l}\text { Hg Stock } \\
\mathrm{mg} \mathrm{m}^{-2}\end{array}$} & \multirow{2}{*}{$\begin{array}{c}\text { CEC } \\
\mathrm{cmol}_{(+)} \mathrm{kg}^{-1}\end{array}$} \\
\hline & & \multicolumn{2}{|c|}{$\mathrm{g} \mathrm{kg}^{-1}$} & & \multicolumn{2}{|c|}{$\mathrm{mg} \mathrm{kg}^{-1}$} & & & \\
\hline \multicolumn{10}{|c|}{ Organic horizons $(\mathrm{O})$} \\
\hline Fir & 120 & $324 \pm 81$ & $25 \pm 12$ & $4.18 \pm 0.34$ & $0.458 \pm 0.121$ & $1.5 \pm 0.4$ & $215 \pm 88$ & $4.1 \pm 1.7$ & $67.7 \pm 15.5$ \\
\hline Pine & 120 & $237 \pm 145$ & $13 \pm 6$ & $4.66 \pm 0.44$ & $0.143 \pm 0.076$ & $0.7 \pm 0.2$ & $147 \pm 37$ & $1.4 \pm 0.7$ & $48.4 \pm 22.7$ \\
\hline \multicolumn{10}{|c|}{ Mineral horizons $(\mathrm{A})(0-10 \mathrm{~cm})$} \\
\hline Fir & 120 & $38 \pm 19$ & $\begin{array}{c}0.4 \pm \\
0.3\end{array}$ & $4.05 \pm 0.24$ & $0.117 \pm 0.067$ & $3.1 \pm 0.1$ & $348 \pm 120$ & $11.2 \pm 5.0$ & 16. $2 \pm 6.5$ \\
\hline Pine & 120 & $25 \pm 17$ & $\begin{array}{c}0.2 \pm \\
0.1\end{array}$ & $4.70 \pm 0.44$ & $0.036 \pm 0.021$ & $1.6 \pm 0.1$ & $209 \pm 65$ & $4.0 \pm 1.8$ & $9.87 \pm 5.1$ \\
\hline
\end{tabular}

Notes: $n$-number of samples, C-carbon, S-sulfur, Hg-mercury, Hg:C-mercury to carbon ratio, Hg:S-mercury to sulfur ratio, CEC-cation exchange capacity.

The overall average $\mathrm{Hg}$ concentrations (irrespective of forest stand, $n=240$ ) were $0.225 \mathrm{mg} \mathrm{kg}^{-1}$ in the $\mathrm{O}$ horizons and $0.075 \mathrm{mg} \mathrm{kg}^{-1}$ in the mineral horizons. The $\mathrm{Hg}$ content in soil differed significantly between the fir and pine stands. The average $\mathrm{Hg}$ concentration in the $\mathrm{O}$ horizons was more than three times greater in fir stands than that in pine stands (Table 2). In the A horizons, the difference was about four-fold. In the O horizons, the $\mathrm{Hg}$ concentration was highest at plot 4 (fir stand, $\mathrm{Hg}=0.781 \mathrm{mg} \mathrm{kg}^{-1}$ ) and lowest at plot 5 (pine stand, $\mathrm{Hg}=0.017 \mathrm{mg} \mathrm{kg}^{-1}$ ). In the A horizons, the highest 
$\mathrm{Hg}$ concentration was at plot 4 (fir stand, $\mathrm{Hg}=0.378 \mathrm{mg} \mathrm{kg}^{-1}$ ) and the lowest was at plot 2 (pine stand, $\mathrm{Hg}=0.01 \mathrm{mg} \mathrm{kg}^{-1}$ ). The $\mathrm{Hg}$ concentration data for all plots were compared using a Kruskal-Wallis test. The plots could be ranked, from highest average $\mathrm{Hg}$ concentration to lowest, as follows: O horizons: plot $4\left(0.519 \mathrm{mg} \mathrm{kg}^{-1}\right) \sim$ plot 3 $\left(0.466 \mathrm{mg} \mathrm{kg}^{-1}\right)>\operatorname{plot} 1\left(0.388 \mathrm{mg} \mathrm{kg}^{-1}\right)>\operatorname{plot} 2\left(0.211 \mathrm{mg} \mathrm{kg}^{-1}\right)>\operatorname{plot} 5\left(0.142 \mathrm{mg} \mathrm{kg}^{-1}\right)>$ plot $6\left(0.083 \mathrm{mg} \mathrm{kg}^{-1}\right)$; A horizons: plot $4\left(0.153 \mathrm{mg} \mathrm{kg}^{-1}\right) \sim$ plot $3\left(0.135 \mathrm{mg} \mathrm{kg}^{-1}\right)>\operatorname{plot} 1$ $\left(0.061 \mathrm{mg} \mathrm{kg}^{-1}\right) \sim$ plot $6\left(0.043 \mathrm{mg} \mathrm{kg}^{-1}\right) \sim$ plot $2\left(0.041 \mathrm{mg} \mathrm{kg}^{-1}\right)>$ plot $5\left(0.023 \mathrm{mg} \mathrm{kg}^{-1}\right)$.

The average $\mathrm{Hg}$ stock in soils (i.e., sum of stocks in the $\mathrm{O}$ and $\mathrm{A}$ horizons) was $10.1( \pm 6.1) \mathrm{mg} \mathrm{m}^{-2}$. The average $\mathrm{Hg}$ stock was three times higher in fir stands $\left(15.3 \pm 5.7 \mathrm{mg} \mathrm{m}^{-2}\right)$ than that in pine stands $\left(5.4 \pm 1.9 \mathrm{mg} \mathrm{m}^{-2}\right)$.

To investigate the effect of duration of exposure to the roadway on soil Hg concentration we compared the data from plots near the roadway opened 8 years ago (four plots, 160 sampling points) to the data from plots with about 35 years of exposure (two plots, 80 sampling points). For fir stands $\mathrm{Hg}$ stocks in the $\mathrm{O}+\mathrm{A}$ horizons were significantly higher near the roadway opened 35 years ago than in soil near the roadway opened 8 years ago, whereas for pine stands there was no significant difference (Figure 2).

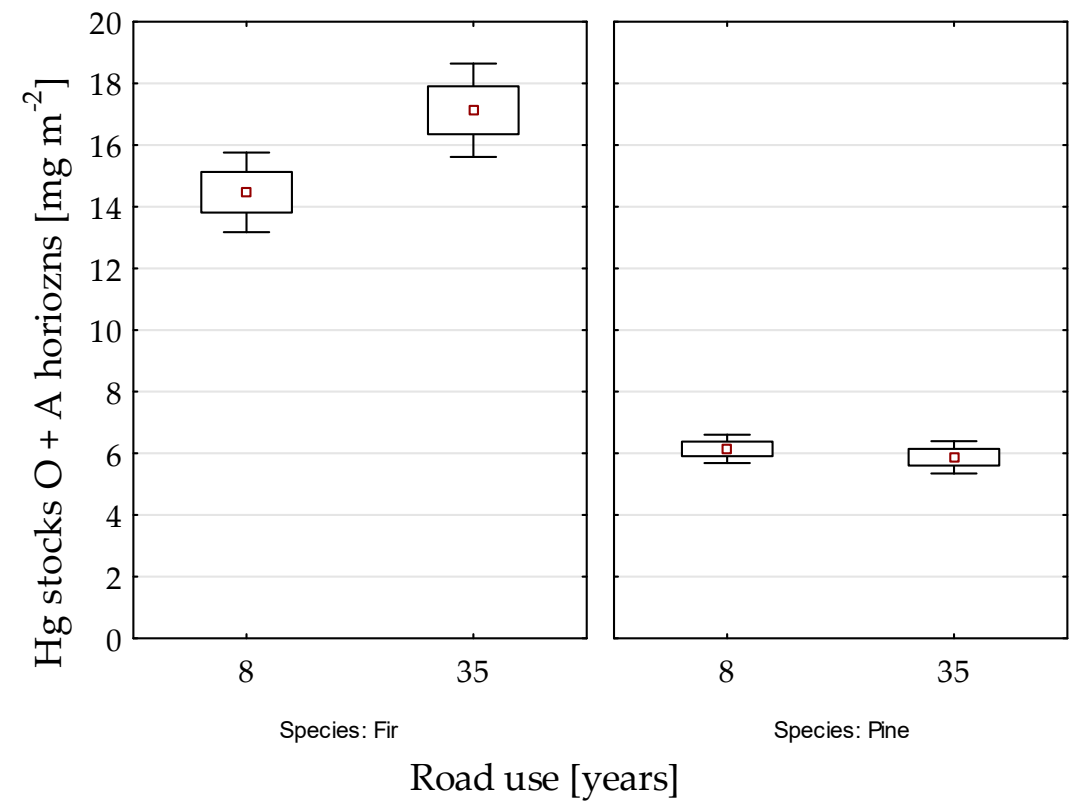

Figure 2. Comparison of $\mathrm{Hg}$ stocks in soils (sum of the $\mathrm{Hg}$ stocks in the $\mathrm{O}$ and $\mathrm{A}$ horizons) near roadways opened to traffic 8 and 35 years ago.

The Hg concentration in soil was significantly $(p<0.05)$ positively correlated with $\mathrm{C}$ content ( $\mathrm{r}=0.48$ and 68 in the $\mathrm{O}$ and A horizons, respectively). To standardize the concentrations of $\mathrm{Hg}$ samples with variable $\mathrm{C}$ content, we calculated the $\mathrm{Hg}: \mathrm{C}$ ratio. The average $\mathrm{Hg}: \mathrm{C}$ ratio in the $\mathrm{O}$ horizons $\left(1.0 \mathrm{mg} \mathrm{Hg} \mathrm{kg}^{-1}\right.$ of $\left.\mathrm{C}\right)$ was about half that in mineral soil (2.3 $\mathrm{mg} \mathrm{Hg} \mathrm{kg}^{-1}$ of $\mathrm{C}$ ). Comparing soils of fir and pine stands, the $\mathrm{Hg}: \mathrm{C}$ ratio in the $\mathrm{O}$ horizons of pine stands was half of that in the $\mathrm{O}$ horizons under fir stands. In the $\mathrm{A}$ horizons, the $\mathrm{Hg}: \mathrm{C}$ ratio was significantly higher than that in the $\mathrm{O}$ horizons, but the difference in values between soils of fir and pine stands was similar. Similar trends were detected for the $\mathrm{Hg}: \mathrm{S}$ ratio; i.e., the $\mathrm{Hg}: \mathrm{S}$ ratio in soils of fir stands was significantly higher than under that pine stands for both the $\mathrm{O}$ and $\mathrm{A}$ horizons (Table 2). The relationships between $\mathrm{C}$ and $\mathrm{Hg}$ concentrations were linear. In the $\mathrm{O}$ horizons, the gradients of the relationships were similar for soils of fir and pine stands, but the intercept was clearly higher for soil of fir stands than for soil of pine stands (Figure 3a). In contrast, for the A horizons, the intercepts were similar but the gradient was steeper for soil of fir stands than for soil of pine stands (Figure $3 b$ ). 


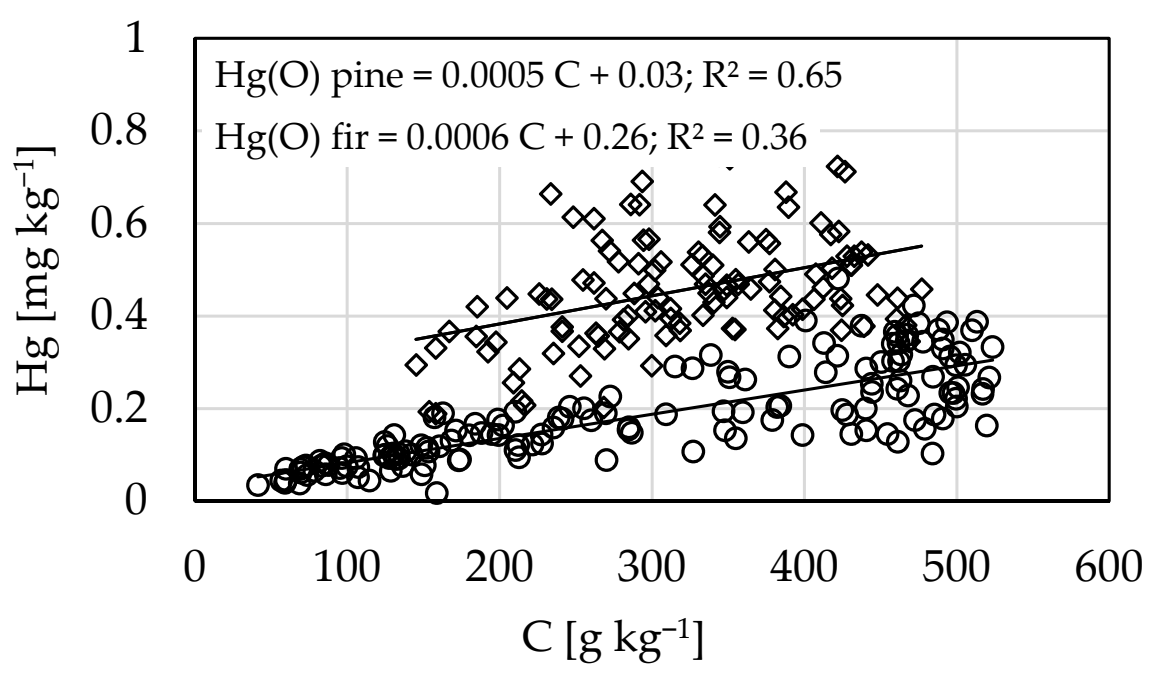

(a)

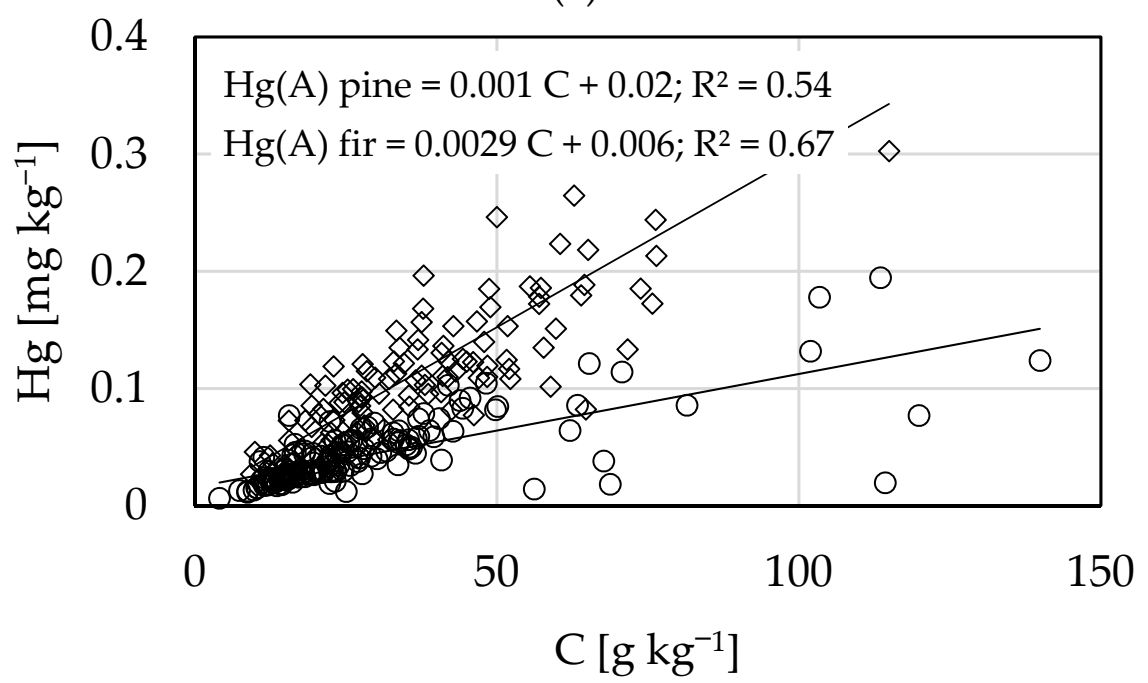

(b)

Figure 3. Relationships between mercury $(\mathrm{Hg})$ and carbon $(\mathrm{C})$ contents in soil of pine $(\bigcirc)$ and fir $(\diamond)$ stands in the $\mathrm{O}(\mathbf{a})$ and $\mathrm{A}(\mathbf{b})$ horizons.

We also investigated the effect of very close proximity $(50 \mathrm{~m})$ to the roadway on $\mathrm{Hg}$ concentrations in forest soils. In the $\mathrm{O}$ horizons, the $\mathrm{Hg}$ concentration was only decreased in close vicinity $(2 \mathrm{~m})$ to the forest edge in fir stands (Figure $4 \mathrm{a}$ ). We detected no clear patterns in the relationships between $\mathrm{Hg}$ concentration and distance to the road in the $\mathrm{O}$ and A horizons of pine and fir stands (Figure 4a,b). We then plotted the $\mathrm{Hg}: \mathrm{C}$ ratio as a function of distance from the road (Figure 5). In the A horizons of fir stands, the $\mathrm{Hg}: \mathrm{C}$ ratio was significantly lower in the plots 2,7 , and $12 \mathrm{~m}$ from the roadway than in plots further from the roadway (Figure $5 b$ ). In contrast, under pine stands, the $\mathrm{Hg} / \mathrm{C}$ ratio slightly increased near the roadway. Such changes were not detected in the O horizons (Figure 5a). 


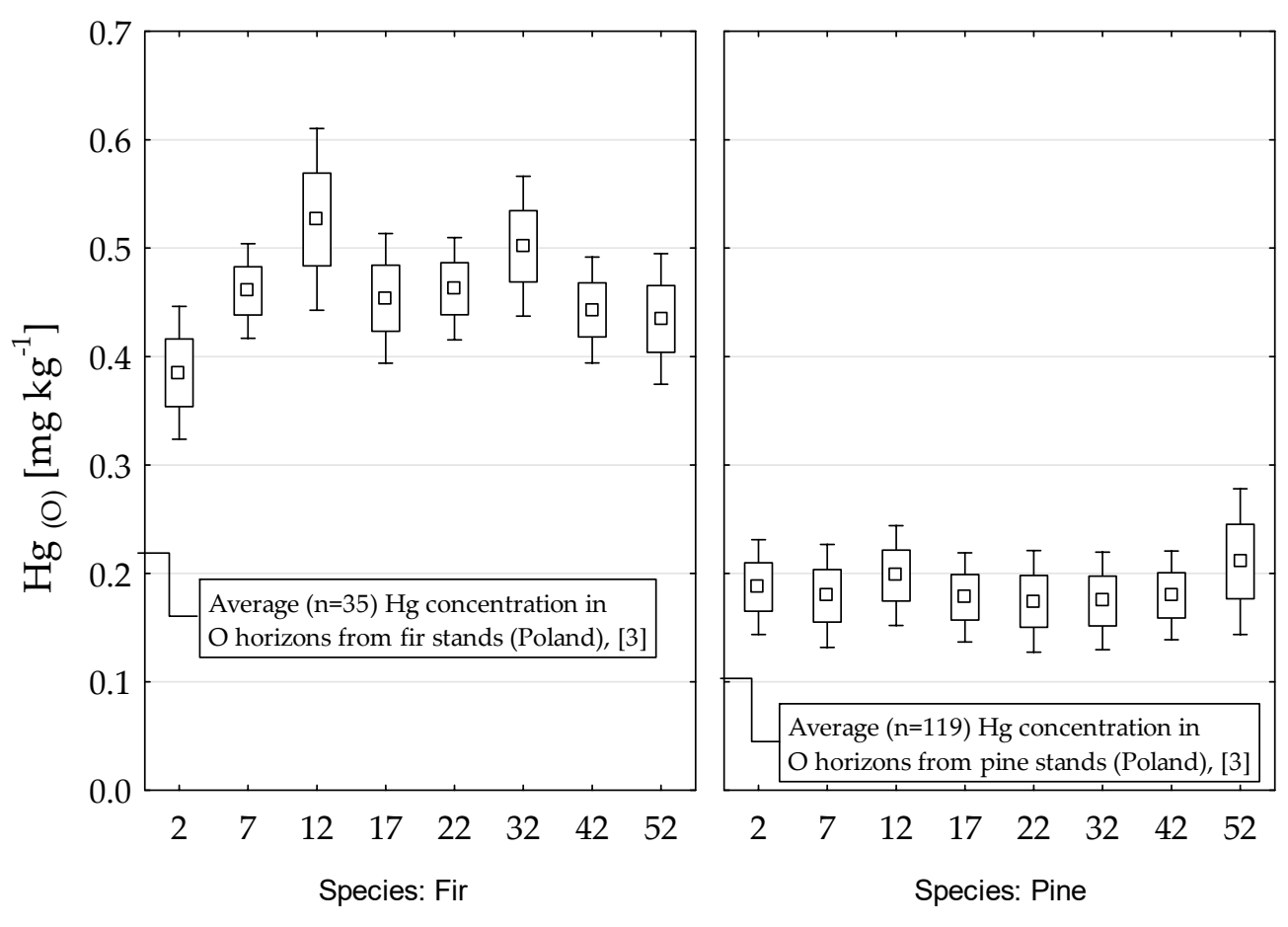

Distance $[\mathrm{m}]$

(a)
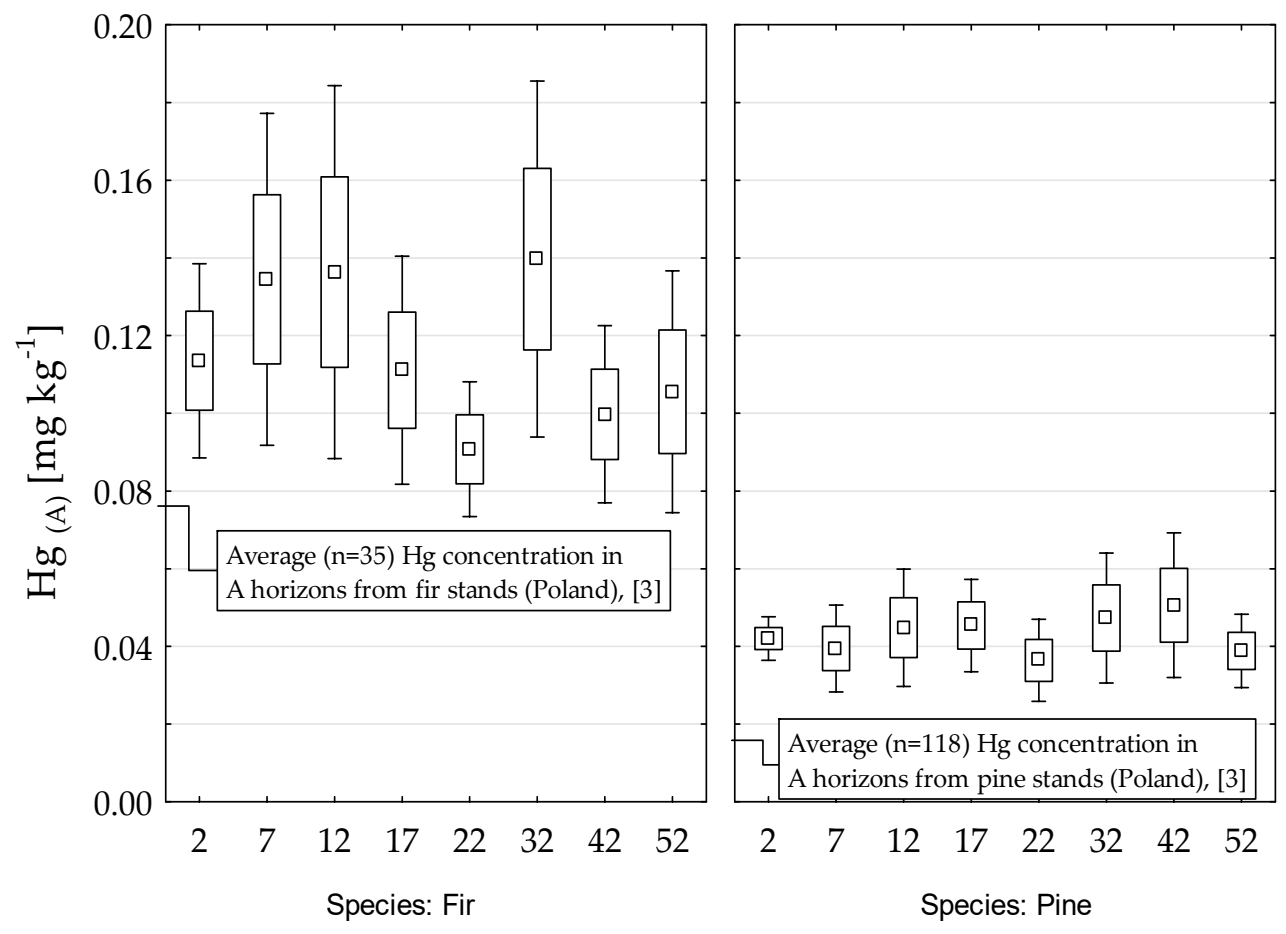

Distance [m]

(b)

Figure 4. Relationship between mercury $(\mathrm{Hg})$ concentration in the $\mathrm{O}(\mathbf{a})$ and $\mathrm{A}(\mathbf{b})$ horizons in soils of fir and pine stands and distance from the roadway. 

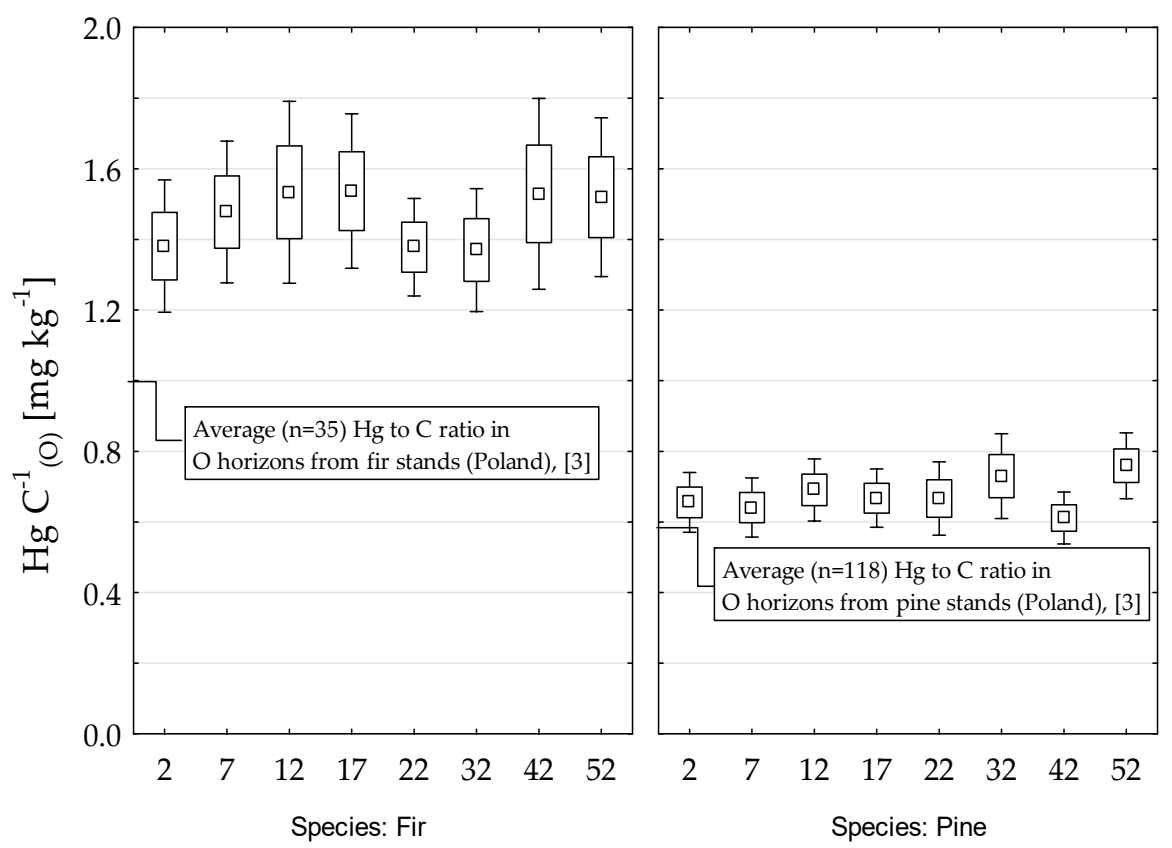

Distance $[\mathrm{m}]$

(a)

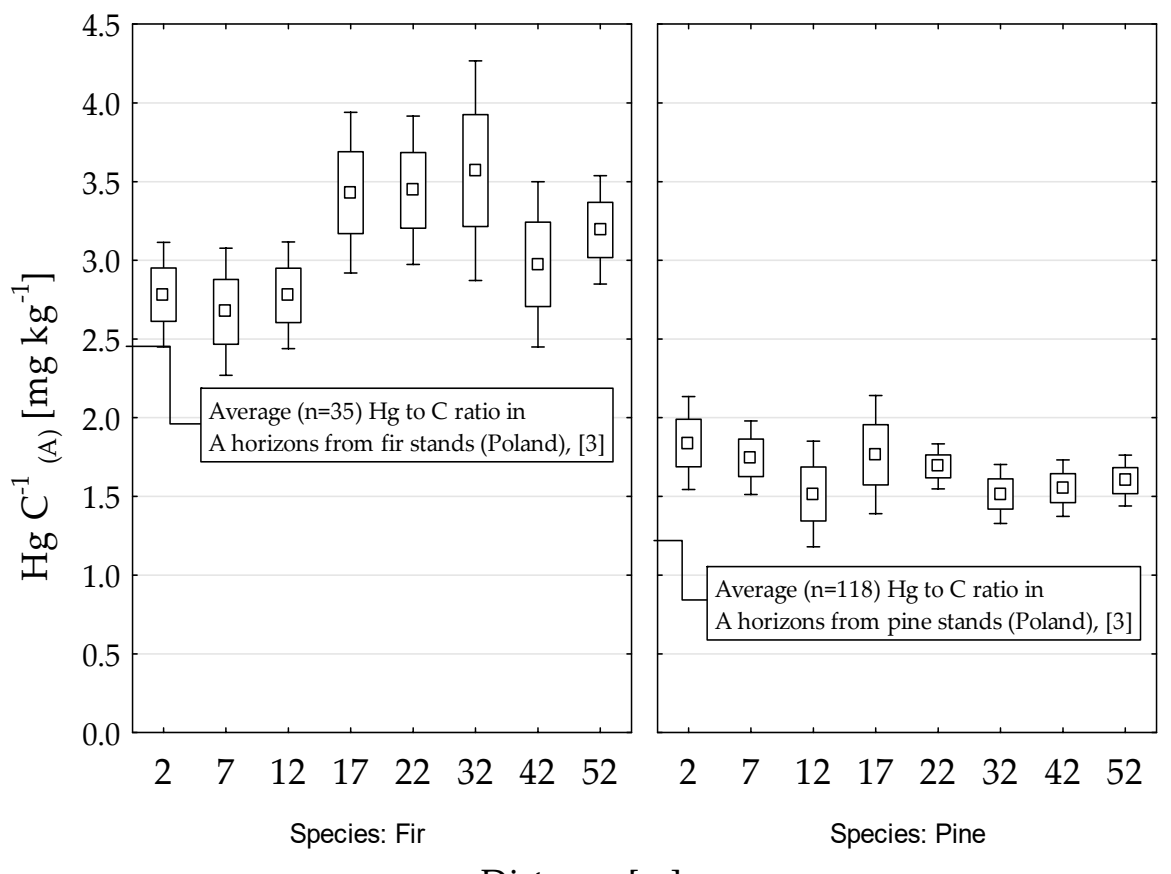

Distance $[\mathrm{m}]$

(b)

Figure 5. Relationship between mercury to carbon ( $\mathrm{Hg}$ :C) ratio in the $\mathrm{O}(\mathbf{a})$ and $\mathrm{A}(\mathbf{b})$ horizons in soils of fir and pine stands and distance from the roadway.

Multiple regression analysis revealed that in both the $\mathrm{O}$ and A horizons, three variables significantly contributed to the model describing the $\mathrm{Hg}$ concentration, namely: the contents of $\mathrm{C}$ and $\mathrm{S}$ and the species (fir or pine), which collectively explained $76 \%$ and $72 \%$ of $\mathrm{Hg}$ concentrations in the $\mathrm{O}$ and $\mathrm{A}$ horizons, respectively. The $\mathrm{C}$ content alone explained $28 \%$ and $43 \%$ of variation in $\mathrm{Hg}$ concentrations in the $\mathrm{O}$ and $\mathrm{A}$ horizons, respectively. In the $\mathrm{O}$ horizons, the $\mathrm{S}$ concentration explained an additional $21 \%$ of the variation in $\mathrm{Hg}$ concentration, whereas the variable "tree species" explained $27 \%$ of the variation in 
$\mathrm{Hg}$ concentration. In the A horizons, the S concentration explained $14 \%$ of the variation in $\mathrm{Hg}$ concentration, whereas "tree species" explained $15 \%$.

\section{Discussion}

Despite close vicinity to the roadway, the soil concentrations of $\mathrm{Hg}\left(0.225 \mathrm{mg} \mathrm{kg}^{-1}\right.$ in the $\mathrm{O}$ horizons and $0.075 \mathrm{mg} \mathrm{kg}^{-1}$ in the A horizons) lay within the ranges reported for weakly polluted areas. In the literature, more available data exist for the mineral A horizons than for the O horizons. The FOREGS Geochemical Atlas [28] reported $0.011 \mathrm{mg} \mathrm{Hg} \mathrm{kg}^{-1}$ for the majority of Poland's territory. For the reference area located ca. $4.75 \mathrm{~km}$ from the highway in the center of the investigated forest area, Gruba et al. [27] reported $0.076 \mathrm{mg} \mathrm{Hg} \mathrm{kg}^{-1}$ in the A horizons (mixed fir-beech-pine stands). Gruba et al. [3] analyzed a large data set from throughout Poland, and detected average values of $0.13 \mathrm{mg} \mathrm{Hg} \mathrm{kg}^{-1}$ and $0.04 \mathrm{mg} \mathrm{Hg} \mathrm{kg}^{-1}$ in the $\mathrm{O}$ and A horizons, respectively. However, most of those data were collected from soil of pine stands.

A broad spectrum of soil parameters can affect the ability of soils to sequester $\mathrm{Hg}$, such as the contents of $\mathrm{C}$ and $\mathrm{S}$, texture, and forest type. The concentrations of total $\mathrm{Hg}$ in soil varied between 0.01 and $0.781 \mathrm{mg} \mathrm{kg}^{-1}$ in this study. The major variable explaining variations in $\mathrm{Hg}$ concentrations was $\mathrm{C}$ content, which reflects the SOM content. In soil, $\mathrm{Hg}$ has a strong affinity for SOM [2,4]. As shown in Figure 3, there was a linear relationship between soil $\mathrm{C}$ content and total $\mathrm{Hg}$ content. Compared with data in other reports [5,27], our results demonstrated quite good linear relationship between $\mathrm{Hg}$ and $\mathrm{C}$ contents, whilstin several studies, the original data were scattered but the relationships become more linear when both variables were log-transformed [5,27].

The $\mathrm{Hg}$ content in soil can be standardized by calculating the $\mathrm{Hg}: \mathrm{C}$ or $\mathrm{Hg}: \mathrm{S}$ ratio. In the soils studied here, the average $\mathrm{Hg}: \mathrm{C}$ ratios in the $\mathrm{O}$ and $\mathrm{A}$ horizons were 1.0 and $2.3 \mathrm{mg} \mathrm{Hg} \mathrm{kg}^{-1} \mathrm{C}$, respectively. Based on the literature, it can be assumed that $\mathrm{Hg}: \mathrm{C}$ ratios depend on the decomposition degree of SOM and continuously increase with soil depth. Gruba et al. [27] reported that the $\mathrm{Hg}: \mathrm{C}$ ratio tends to increase with the soil depth. They found 2.8 and $4.4 \mathrm{mg} \mathrm{Hg} \mathrm{kg}^{-1} \mathrm{C}$ in the topsoil and subsoil horizons, respectively. Moreover, Navratil et al. [7] observed a clear increase in the $\mathrm{Hg}: \mathrm{C}$ ratio with increasing depth. For a set of forest soils in Poland, Gruba et al. [3] found that $\mathrm{Hg}: \mathrm{C}$ ratios increased with depth: i.e., $0.7,1.7,2.7$, and $5.3 \mathrm{mg} \mathrm{Hg} \mathrm{kg}^{-1} \mathrm{C}$ in the $\mathrm{O}$ and mineral $0-10 \mathrm{~cm}, 10-40 \mathrm{~cm}$ and $40-100 \mathrm{~cm}$ layers, respectively.

There is very little information about the effect of roadways on the accumulation of $\mathrm{Hg}$ in soils. In Poland, the highest concentrations of $\mathrm{Hg}$ have been detected near mining sites (such as black coal, copper, and other metal ore mines in Silesia region) or smelters [29]. Effects of road is usually attributed to chemical composition of road dust [11,12], which contribute significantly to global $\mathrm{Hg}$ pollution [15]. Our data does not clearly show the effect of road on $\mathrm{Hg}$ accumulation near the road. However, the comparisons (see Figures 4 and 5) with the average concentration of $\mathrm{Hg}$ from the reference area [27] or with average values from Polish forest soils [3] suggested that $\mathrm{Hg}$ accumulation can be enhanced near the roadway, but only in soil of fir stands. Also the comparison shown in Figure 2 imply that there is no significant effect of exposure duration ( 8 or 35 years) on accumulation of $\mathrm{Hg}$, but rather the effect of tree species.

Our data indicate a strong impact of the tree species on $\mathrm{Hg}$ concentrations in both $\mathrm{O}$ and mineral A horizons. Previous studies [19,23] have concluded that the effect of the dominant tree species is significant only for the $\mathrm{O}$ horizon i.e., the soil $\mathrm{Hg}$ content in the organic horizon, but not the mineral horizons, is affected by the dominant tree species (pine, spruce, and fir) [3]. However, our results are consistent with those of Navrátil et al. [24], who found higher $\mathrm{Hg}$ concentrations at all mineral soil depths under beech stands than under spruce stands. A scavenging effect of vegetation on $\mathrm{Hg}$ has been suggested by several authors, that the enhanced deposition under coniferous forest is probably related to the large area of needles year-round to capture $\mathrm{Hg}$ from the atmosphere [19,22]. However, differences in forest species are usually combined with differences in orographic precipitation along an 
elevational gradient. In our study, the elevation of the fir and pine stands was roughly the same, so it was possible to detect differences in their scavenging effects.

The average $\mathrm{Hg}: \mathrm{C}$ ratios were also found to be strongly dependent on tree species. The trends illustrated in Figure 3 suggest that organic matter of fir stands has more $\mathrm{Hg}$ per unit of $C$. The gradients of the relationships, which reflect the effectiveness of SOM to bind $\mathrm{Hg}$, were similar in soils from pine and fir stands in the $\mathrm{O}$ horizons but different in the A horizons. In the A horizons, Hg entered more effectively the soils of fir stands than soils of pine stands. This suggested that the decomposition process enhanced the ability of fir SOM to bind $\mathrm{Hg}$. Considering the effect of tree species on the $\mathrm{Hg}: \mathrm{C}$ ratio, Navratil et al. [7] found that the $\mathrm{Hg}: \mathrm{C}$ ratio was higher in soils of spruce stands than in soils of beech stands. Obrist et al. [30] showed that the $\mathrm{Hg}: \mathrm{C}$ ratios were higher in soils from coniferous stands than in soils of deciduous stands, despite of soils with similar $\mathrm{Hg}$ concentrations. In addition, Gruba et al. [3] found that soils of fir stands had a higher level of $\mathrm{Hg}$ saturation than soils in stands of other species did, such as pine and oak.

Similar to the $\mathrm{Hg}: \mathrm{C}$ ratio, the $\mathrm{Hg}: \mathrm{S}$ ratio appeared to be species dependent, i.e., the $\mathrm{Hg}: \mathrm{S}$ ratios were significantly higher in soils of fir stands than in soils of pine stands. The data presented in Figure 5 revealed an interesting decline in the $\mathrm{Hg}: \mathrm{C}$ ratio in the A horizons of soils of fir stands very close (up to $12 \mathrm{~m}$ ) to the road edge. This decline was followed by a decrease in $S$ content (but not organic $C$ content), implying that soil under fir stands close to the road contained fewer thiol groups able to bind $\mathrm{Hg}[1,2]$. We hypothesize that this is an effect of enhanced decomposition of SOM in this type of stand because of its microclimate. Fir is a shade-tolerant species, and soils of fir stands receive little solar energy. New roads through fir stands affect the local microclimate more than do new roads through pine stands.

In the case of fir stands, changes in forest stand density (e.g., thinning), lead to increase in the decomposition of SOM, and, in the effect, possibly result in the mobilization of $\mathrm{Hg}$ accumulated in the organic horizons [31], in higher amounts than in pine stands. The increased transport of $\mathrm{Hg}$ in stream waters from forest stands were recognized as a joint result of site preparation and logging by Eklöf et al. [32]. Decaying organic materials also cause a significant increase in $\mathrm{Hg}$ leaching during the first several years after harvest [33].

\section{Conclusions}

The concentrations of $\mathrm{Hg}$ in soils adjacent to the roadway were slightly higher than ranges reported for unpolluted areas. The concentrations of $\mathrm{Hg}$ were not increased in very close proximity (up to $50 \mathrm{~m}$ ) to the road. Moreover, compared with the average concentration of $\mathrm{Hg}$ from the reference area or with average values from Polish forest soils, $\mathrm{Hg}$ accumulation was similar or only slightly enhanced near the road. Thus, our results do not confirmed a clear effect of road on soil pollution with $\mathrm{Hg}$. In contrast to other reports, our study detected a strong effect of tree species on $\mathrm{Hg}$ concentrations in both the $\mathrm{O}$ and mineral A horizons. Although both pine and fir are coniferous species they have different abilities to sequester $\mathrm{Hg}$. The major variable explaining variations in soil $\mathrm{Hg}$ concentrations was soil $\mathrm{C}$ content. In addition, the average $\mathrm{Hg}: \mathrm{C}$ ratio was strongly dependent on tree species, i.e., organic matter of fir stands had more $\mathrm{Hg}$ per unit of $\mathrm{C}$. In fir stands, a change in forest stand density (e.g., thinning or clear-cutting) can increase the decomposition rate of SOM. This may result in greater mobilization of $\mathrm{Hg}$ pools accumulated in the organic horizons than in pine stands. The result of this study should not be interpreted as downgrading of roads as source of $\mathrm{Hg}$ pollution. We suggest that the assessment of $\mathrm{Hg}$ pollution should take into account variables governing the concentrations of $\mathrm{Hg}$ in soils, particularly the content of SOM.

Author Contributions: Conceptualization, P.G.; data curation, P.G., M.K., D.K. and M.P.; methodology, P.G. and M.P.; validation, D.K., M.K. and P.G.; investigation, D.K., M.K., M.P. and P.G.; project administration, P.G.; writing-original draft preparation, P.G.; writing—review and editing, P.G., M.K., D.K., M.P.; visualization, P.G. and D.K.; funding acquisition, P.G. All authors have read and agreed to the published version of the manuscript. 
Funding: This research was funded by the National Science Centre (NCN), Poland, agreement number UMO-2017/25/B/ST10/02128.

Institutional Review Board Statement: Not applicable.

Informed Consent Statement: Not applicable.

Data Availability Statement: The data presented in this study are available on request from the corresponding author.

Acknowledgments: We thank Jennifer Smith for editing a draft of this manuscript.

Conflicts of Interest: The authors declare no conflict of interest.

\section{References}

1. Grigal, D.F. Mercury sequestration in forests and peatlands. J. Environ. Qual. 2003, 32, 393-405. [CrossRef] [PubMed]

2. Skyllberg, U. Mercury Biogeochemistry in Soils and Sediments. Dev. Soil Sci. 2010, 34, 379-410. [CrossRef]

3. Gruba, P.; Socha, J.; Pietrzykowski, M.; Pasichnyk, D. Tree species affects the concentration of total mercury (Hg) in forest soils: Evidence from a forest soil inventory in Poland. Sci. Total. Environ. 2019, 647, 141-148. [CrossRef] [PubMed]

4. Steinnes, E. Mercury in Heavy Metals in Soils. In Heavy Metals in Soils, 2nd ed.; Alloway, B.J., Ed.; Springer: Dordrecht, The Netherlands, 1995; pp. 222-236.

5. Szopka, K.; Karczewska, A.; Kabała, C. Mercury accumulation in the surface layers of mountain soils: A case study from the Karkonosze Mountains, Poland. Chemosphere 2011, 83, 1507-1512. [CrossRef]

6. Demers, J.D.; Blum, J.D.; Zak, D.R. Mercury isotopes in a forested ecosystem: Implications for air-surface exchange dynamics and the global mercury cycle. Glob. Biogeochem. Cycles 2013, 27, 222-238. [CrossRef]

7. Navrátil, T.; Shanley, J.; Rohovec, J.; Hojdová, M.; Penížek, V.; Buchtová, J. Distribution and Pools of Mercury in Czech Forest Soils. Water Air Soil Pollut. 2014, 225, 1-17. [CrossRef]

8. Pant, P.; Allen, M. Interaction of Soil and Mercury as a Function of Soil Organic Carbon: Some Field Evidence. Bull. Environ. Contam. Toxicol. 2007, 78, 539-542. [CrossRef]

9. Swain, E.B.; Engstrom, D.R.; Brigham, M.E.; Henning, T.A.; Brezonik, P.L. Increasing Rates of Atmospheric Mercury Deposition in Midcontinental North America. Science 1992, 257, 784-787. [CrossRef] [PubMed]

10. Lorey, P.; Driscoll, C.T. Historical Trends of Mercury Deposition in Adirondack Lakes. Environ. Sci. Technol. 1999, 33, 718-722. [CrossRef]

11. Lu, X.; Li, L.Y.; Wang, L.; Lei, K.; Huang, J.; Zhai, Y. Contamination assessment of mercury and arsenic in roadway dust from Baoji, China. Atmos. Environ. 2009, 43, 2489-2496. [CrossRef]

12. Shakya, P.R.; Pradhananga, A.R. Determination and contamination assessment of $\mathrm{Pb}, \mathrm{Cd}$, and $\mathrm{Hg}$ in roadside dust along Kathmandu-Bhaktapur road section of Arniko highway, Nepal. Res. J. Chem. Sci. 2013, 3, 18-25.

13. Jiang, G.-B.; Shi, J.-B.; Feng, X.-B. Mercury Pollution in China. Environ. Sci. Technol. 2006, 40, 3672-3678. [CrossRef]

14. Petroleum Statistics. Information Service, Institute of Petroleum in BP Statistical Review of World Energy; Petroleum Economist: London, UK, 1995.

15. Pirrone, N.; Cinnirella, S.; Feng, X.; Finkelman, R.B.; Friedli, H.R.; Leaner, J.; Mason, R.; Mukherjee, A.B.; Stracher, G.; Streets, D.G.; et al. Global Mercury Emissions to the Atmosphere from Natural and Anthropogenic Sources. In Mercury Fate and Transport in the Global Atmosphere; Pirrone, N., Mason, N., Eds.; Springer: Berlin/Heidelberg, Germany, 2009 ; pp. 1-47.

16. Liu, Q.; Liu, Y.; Zhang, M. Mercury and Cadmium Contamination in Traffic Soil of Beijing, China. Bull. Environ. Contam. Toxicol. 2011, 88, 154-157. [CrossRef] [PubMed]

17. Liang, L.; Horvat, M.; Danilchik, P. A novel analytical method for determination of picogram levels of total mercury in gasoline and other petroleum based products. Sci. Total. Environ. 1996, 187, 57-64. [CrossRef]

18. Ozaki, H.; Watanabe, I.; Kuno, K. As, $\mathrm{Sb}$ and $\mathrm{Hg}$ distribution and pollution sources in the roadside soil and dust around Kamikochi, Chubu Sangaku National Park, Japan. Geochem. J. 2004, 38, 473-484. [CrossRef]

19. Blackwell, B.D.; Driscoll, C.T. Deposition of Mercury in Forests along a Montane Elevation Gradient. Environ. Sci. Technol. 2015, 49, 5363-5370. [CrossRef] [PubMed]

20. Zimka, J.R.; Stachurski, A. Forest decline in Karkonosze Mts. (Poland). Part II. An analysis of acidity and chemistry of at-mospheric precipitation, troughfall and forest steramwaters. Ekol. Pol. 1996, 44, 153-177.

21. Gruba, P. The influence of trees on spatial variability of $\mathrm{pH}$ in top horizons of forest soil. Sylwan 2009, 153, 330-335.

22. Stankwitz, C.; Kaste, J.M.; Friedland, A.J. Threshold Increases in Soil Lead and Mercury from Tropospheric Deposition across an Elevational Gradient. Environ. Sci. Technol. 2012, 46, 8061-8068. [CrossRef] [PubMed]

23. Richardson, J.B.; Friedland, A.J. Mercury in coniferous and deciduous upland forests in northern New England, USA: Implications of climate change. Biogeosciences 2015, 12, 6737-6749. [CrossRef]

24. Navrátil, T.; Shanley, J.B.; Rohovec, J.; Oulehle, F.; Šimeček, M.; Houška, J.; Cudlín, P. Soil mercury distribution in adjacent coniferous and deciduous stands highly impacted by acid rain in the Ore Mountains, Czech Republic. Appl. Geochem. 2016, 75, 63-75. [CrossRef] 
25. Krajewski, R. Detailed Geological Map of Poland 1:50,000; Polish Geological Institute: Warsaw, Poland, 1955.

26. IUSS Working Group WRB. World Reference Base for Soil Resources. Available online: http://www.fao.org/3/a-a0510e.pdf (accessed on 22 March 2021).

27. Gruba, P.; Błońska, E.; Lasota, J. Predicting the Concentration of Total Mercury in Mineral Horizons of Forest Soils Varying in Organic Matter and Mineral Fine Fraction Content. Water Air Soil Pollut. 2014, 225, 1-9. [CrossRef]

28. FOREGS. Part 1-Background Information, Methodology and Maps. In EuroGeoSurveys in Geochemical Atlas of Europe; Salminen, R., Ed.; Geological Survey of Finland: Espoo, Finland, 2014.

29. Medynska-Juraszek, A.; Kabala, C. Lead, mercury and cadmium in forest soils impacted by copper smelting in south-west Poland. In Proceedings of the 15th International Conference on Heavy Metals in the Environment, Gdansk, Poland, 19-23 August 2010; p. 793.

30. Obrist, D.; Johnson, D.W.; Edmonds, R.L. Effects of vegetation type on mercury concentrations and pools in two adjacent coniferous and deciduous forests. J. Plant. Nutr. Soil Sci. 2012, 175, 68-77. [CrossRef]

31. Pokharel, A.K.; Obrist, D. Fate of mercury in tree litter during decomposition. Biogeosciences 2011, 8, 2507-2521. [CrossRef]

32. Eklöf, K.; Schelker, J.; Sørensen, R.; Meili, M.; Laudon, H.; Von Brömssen, C.; Bishop, K. Impact of Forestry on Total and Methyl-Mercury in Surface Waters: Distinguishing Effects of Logging and Site Preparation. Environ. Sci. Technol. 2014, 48, 4690-4698. [CrossRef] [PubMed]

33. Zhang, H.; Yin, R.-S.; Feng, X.-B.; Sommar, J.; Anderson, C.W.N.; Sapkota, A.; Fu, X.-W.; Larssen, T. Atmospheric mercury inputs in montane soils increase with elevation: Evidence from mercury isotope signatures. Sci. Rep. 2013, 3, 3322. [CrossRef] [PubMed] 